\title{
Research on the Development of National Music in the New Media Era
}

\author{
XieChaoying
}

\author{
Linyi University, Linyi, Shandong, China \\ Chaoying007@163.com
}

Keywords: National music; New media era; Music development

\begin{abstract}
National music is the treasure of Chinese art, which is highly artistic and national. The development of national music has some new features in the new era. This paper analyzes the new characteristics of the development of national music in the new media era, and then gives some suggestions of the development of national music in the new media era in order to provide reference for relevant researchers.
\end{abstract}

\section{Concept of New Media and National Music}

The term new media was born in 1960s in America, which was mainly refers to television in that era. The concept of new media has developed with the development of the times. Nowadays, it mainly refers to the new media based on digital technology and the internet technology. About 5 years ago, the new media is mainly refers to the official website, online community, blog, podcast, QQ group etc. Now, the new media in the mobile internet era more refers to the micro blog, wechat, mobile phone applications in the mobile phone terminal media form. Compared with the traditional media, new media has many incomparable advantages in information dissemination. This is the new media is different from traditional media newspapers, radio, television and the most significant difference. In the traditional media, the disseminator of information dissemination of information, the information receiver to receive information passively, not with the information publisher to interact. The new media makes the release of information interaction and information receiver, forward information receivers can be transformed into information publisher. Compared with the traditional media, new media is not limited by time, at any time by writing, publishing information platform. In the new media era, everyone can be customized according to the needs of personalized information, making information more efficient.

National music, also called folk music,means the music of the Chinese nation. It isa kind of cultural form peculiar to 56 nationalities, including Han, whichis the concentrated reflection of people of all ethnic groups in China in the long-term production. Because of the nation's history, geography and customs are different, make our national music form is very rich. All kinds of music, as the nation, region, school and so different in style, there are obvious differences. These differences clearly reflect the characteristics of different nationalities. Folk music is the concentration of national culture, is one of the nation's means of understanding, and is also the national culture and national emotion accumulation. It embodies a nation's spiritual life. Folk music can express emotion between people and people, unite the national spirit. Therefore, folk music has distinctive ethnic characteristics. National music contains a unique artistic form of its own cultural value and aesthetic embodiment.

\section{Features of Development of National Music in New Media Era}

Feature of Openness. The new media breaks the traditional music media time and space constraints. Media users can at any time, any place for various types of music video, audio, image and text. The opening of cross time and make the whole world into a global village, all from different regions have different cultural background music can be displayed in the new media. You can get the most people remain within doors, rich, various music the most cutting-edge music information. Because of the new media forms, gives everyone the maximum possible dissemination of music and music to accept the opportunity. Participants can communicate through their own 
platform, which makes anyone can become the main platform. Anyone can exchange music in the new media network, mobile phone and so on. Everyone can become producers and disseminators of music information in the context of new media. The subject of popular music communication has expanded to the hitherto unknown situation.

Features of Interactive. The spread way of traditional musicis the way as the center is unidirectional. It is spread from the point to the surface. The new media is from point to point, point and surface, and the spread of multi surface and surface interaction. The interactive relationship between the media and the audience, the audience and the audience has established. When the music information communicators will be uploaded to the Internet, the receiver can immediately respond, and timely feedback to the original communicator, can also be forwarded to other people, two-way interaction, interactive information. Therefore, people in the network communication and the audience, also plays a dual role. The music information updated to state communication, real-time bidirectional communication, and timely communication range, more than any previous media. The spread of information including text, sound, images, images, and data symbols. Music information can upload, download, copy, print and you can always find the needed music.

Features of International.National music is an important part of national culture, collision and exchange of world culture, led to the diversification of the field of music development. In the background of today's multicultural restructuring, China folk music tend to the local culture and the inherent advantage of its role, the national culture and national spirit as the core, the arts and culture to the world, forming a spreading tendency in the world. As a product of high technology, new media has brought great change to the communication, is the focus of the future development of the media, the media is the development trend of the market and the inevitable direction. New media technology promotes the spread of ethnic music, for the development of folk music has opened up a broader space. In the long history of Chinese national music, the creation of the widely drawn based on, good words, drama and original ecological folk music, and the cultural differences of ethnic minorities and regions has created today's Chinese national music culture.

\section{Suggestions of Development of National Music in New Media Era}

Elaborate Music Works. The Chinese national music culture has a long history and many varieties of music. It is difficult to spread all varieties of music to the world. We should carry out scientific combing according to its essence, to its dregs, selection and refinement of traditional music culture in China ideological value, wide influence, people love to see and hear the music spread, take the initiative to create media space, traditional music culture of quality, so that people from the "music" of the understanding of traditional music, love traditional music. The development of power industry, expand the communication space, convenient function of virtual space with public management of new media technology in the development, improve the level of innovation. By combining the above method with the national music industry, promote folk music under the new media environment development. We should strengthen the public management of the national music industry promotion and dissemination of culture, communication and ensure the healthy and orderly development of national music under the new media environment. The essences of work to maintain their original style let people learn from traditional music aesthetic quality and historical implication.

Create Music Platform.We cultivate students' deep feelings of national music using the emotional education as the main line and the new media as channels. Folk music is the source of all, China ethnic folk songs of Inner Mongolia folk songs and cover and contain everything, for example, the vast folk melody, beautiful, the North Shaanxi folk song sonorous, all the people to enjoy the beauty. To enjoy the national music as an opportunity, to students' self-feelings as the basis, to inspire students to expand the image of the wings, so that students will continue their emotional understanding of folk music and folk music appreciation coordinated, to become the emotional experience of student's activities. We need to gradually establish a new media platform of folk music with the public service for the purpose, to strengthen the national music lovers, beginners, platform construction professionals and the conduction of the education system, make 
full use of new media influence and force, sharing platform for national music enthusiasts to create a wide audience network. As a product of high technology, new media has brought great change to the communication, is the focus of the future development of the media, the media is the development trend of the market and the inevitable direction. New media technology promotes the spread of ethnic music and opens up a a broader space for the development of nationalmusic.

Strengthen Music Protection. As a developing country with 5000 years of civilization, the ancestors left rich cultural heritage of traditional music for us. The living condition of the music culture is our inexhaustible are inexhaustible source of creation. But due to the change of society, the survival status of Chinese traditional music culture is not optimistic; sharply reduce the traditional music of young people, the community of traditional music culture showed indifference and contempt. In this situation, we should use the digital network technology the characteristics of convenience, interactivity, etc., to promote public actively spread the traditional music culture, to create a love of traditional music, traditional music, traditional music heritage innovation atmosphere, and strive to make our traditional music culture. With the economic globalization, market integration advancement, the world cultural exchange and collision have become increasingly frequent, raised the consciousness of protecting intangible cultural, various countries for the national cultural heritage included in the human representative list of the intangible cultural heritage, to look forward to the dissemination and development of minority culture. Based on this, our country started to excavate the intangible cultural region, folk music in this process has been widely spread and inheritance. It has been our mission to retain the traditional music heritage culture.

Promote Music Internationalization. The openness of new media fast makes more convenient communication between countries all over the world. We should give full play to the advantages of modern media technology. We strengthen the refining and dissemination of traditional music culture essence, active in the Chinese traditional music culture to the world. In addition, we not only carry forward the excellent, the essence of China music culture, but also in dealing with the relationship between traditional music culture and modern music culture, folk music culture and foreign music culture at the same time, reform and innovation of traditional music. The works show received a warm welcome in the foreign countries, to conquer the foreign audience, is reputed to be very wealthy Chinese classical style "China style". Mei Xi'an evaluated this work as"showing high creation and a real talent, and perfect Chinese way of thinking and conception of European music fusion". The success of these works gave us a good enlightenment. We should create some excellent Chinese new music, and with the help of modern media to the world, as he's loved and accepted. Any kind of art culture is the nation's and the world's development, it cannot do without communication with other art forms and fusion, China folk music should also keep it to the world in the nation, at the same time, to the higher realm of art. Folk music is an important part of Chinese music culture, which contains rich cultural connotation of history. All ethnic groups in their own voice and music cultural heritage ideological characteristics, the national spirit with the code unique across time and space, it is the carrier of art of national spirit and national spirit. In the pluralistic world of music, all music is equal and independent. Therefore, we cannot simply measure our national music with the western music theory and techniques of value.

\section{Conclusion}

The fundamental purpose of music education is to cultivate all-round development of people. With the development of the emergence of new media and new technology, the traditional Chinese culture in the face of dive and the influence of western culture has a variety of cultural conflicts. We should not only strengthen the protection and identification of folk music, but also with the new media network platform better inheritance and development of folk music. In the process of development of Chinese national music, we should elaborate music works, create music platform, strengthen music protection and promote music internationalization to make the sound and rapid development of national music in new media era. 


\section{References}

[1] Z.J. Zhou. Study on Spread and Development of National Music in Western Development Movement, Journal of Bijie University. 2(2006) 66 - 70.

[2] X.J. Hu, M.Y. Lai. Inheritance and Innovation: on the Contemporary China National Music Development under the Globalized Visual, Journal of Jincheng Institute of Technology. 5(2013) 29 $-31$

[3] Z.X. Wang.From Original Music to See the Diversified Development of China's National Vocal Music, J.Jilin Normal University Journal(Humanities \& Social Science Edition). 1(2014) 119 $-121$

[4] X.H. Li.Research on the Influence of New Media on Folk Music Development, Journal of Jincheng Institute of Technology. 7(2013) 106 - 107 